\title{
The application of production planning approach on a large number of residential building construction project post natural disaster
}

\author{
Adnan Fadjar ${ }^{1, *}$ \\ ${ }^{1}$ Civil Engineering Department, Tadulako University, Palu, Indonesia
}

\begin{abstract}
After a large-scale natural disaster struck an urban area a large number of residential buildings construction is often needed. Such residential buildings are often built with more or less similar size and model therefore the construction is repetitive. The project management approach is normally employed in managing a large-scale residential building project. This study argues that due to its repetitive nature the construction of a large number of similar houses can also be viewed as a production system in addition to a project view. This study investigates the utilization of the production planning approach with the aid of a discrete event simulation method in managing the construction of a large number of residential buildings. This study simulates the construction of 500 similar houses. The study results show that the production management approach has the potential in managing a large-scale residential building project in addition to the project management approach.
\end{abstract}

\section{Introduction}

An earthquake with 7.4 magnitudes along with tsunami and liquefaction hit Palu City and its surrounding areas on 28 September 2018. The triple large-scale natural disaster caused the loss of thousands of lives and houses. After the disaster, thousands of houses needed to be reconstructed in many locations in Palu and its surrounding areas. The model and size of the houses in one location are often more or less similar, therefore the construction process is repetitive and can be compared with the conveyor belt system in manufacturing [1-6]. This study analyses the completion time of large-scale house construction when it is viewed as a manufacturing process.

\section{Literature Review}

There are two methods frequently used in planning namely activity-based planning and workflow planning $[2,7]$.

\footnotetext{
* Corresponding author: adnan.fadjar@gmail.com
} 


\subsection{Activity-based planning method}

Construction planning in conventional construction project mainly focuses on the project's activities. This planning approach is called activity-based planning or project planning [7]. The critical path method is an example of an activity-based planning method [8].

In the activity-based planning method, the duration of each activity is a function of the work quantity and the production rate of the employed resources [9] as shown in Equation 1.

$$
\text { Activity duration }=\frac{\text { work quantity }}{\text { production rate }}
$$

The activity-based planning method implies that the project completion time is solely determined by the summation of all the critical activity duration. Hence, the project completion time is only changed when its critical activity durations are changed [10].

\subsection{Workflow-based planning method}

The workflow-based planning method is the basis of production system planning which is commonly used in the manufacturing industry. The workflow-based planning method is also called production planning [11-13]. In the workflow-based planning method, the cycle time is a function of the work in process and the throughput as shown in Equation 2 which is also known as Little's Law [14].

$$
\text { Cycle time }=\frac{\text { Work in process }}{\text { Throughput }}
$$

The cycle time is the average time needed to finish one product, the work in process is the average number of products in the production system, and the throughput is the average output of the production system per time unit [14].

To analyze the correlation between the throughput, the work in process, and the cycle time in the construction of a large number of houses, this study uses the SIMUL8 application which is based on the discrete event simulation method. The discrete event simulation method is a simulation method that is commonly used in quantitative analysis of a construction process [15-17]

\section{Definitions and assumptions}

\subsection{Definitions}

In this study project duration is the completion time of 500 houses; the cycle time is the completion time of a single house; the throughput is the number of houses that can be completed per day; the work in process is the number of houses under construction; the interarrival time is the time between the commencement of each house.

\subsection{Assumptions}

In this study, it is assumed that all the houses have similar size and model; there is only one group of workers available for each activity; no parallel activities; and an activity duration is deterministic. 


\section{Model and simulation}

Typical activities in single-story house construction withs their identifications and durations are shown in Table 1.

Table 1 Single story house construction activities and durations

\begin{tabular}{lllc}
\hline No. & Activity & ID & Duration (day) \\
\hline 1 & Foundation & A & 10 \\
\hline 2 & Wall & B & 14 \\
\hline 3 & Roof and fascia & C & 7 \\
\hline 4 & Ceiling frame & D & 3 \\
\hline 5 & Electrical installation & E & 3 \\
\hline 6 & Ceiling fix & F & 3 \\
\hline 7 & Plumbing & G & 6 \\
\hline 8 & Floor tile & H & 5 \\
\hline 9 & Bathroom and toilet & I & 5 \\
\hline 10 & Doors and windows & J & 7 \\
\hline 11 & Painting and finishing & $\mathrm{K}$ & 5 \\
\hline
\end{tabular}

Since this study assumes that there are no parallel activities, hence the construction starts with the foundation activity then followed by the wall, and so on as depicted in Figure 1.

By using the critical path method, it is determined that the completion time for a single house is 68 days.

\begin{tabular}{|c|c|c|c|c|c|c|c|c|c|c|}
\hline Foundation & Wall & $\begin{array}{c}\text { Roof \& } \\
\text { fascia }\end{array}$ & $\begin{array}{l}\text { Ceiling } \\
\text { frame }\end{array}$ & $\begin{array}{l}\text { Electrical } \\
\text { installation }\end{array}$ & $\begin{array}{l}\text { Ceiling } \\
\text { fix }\end{array}$ & $\rightarrow \quad$ Plumbing & $\begin{array}{l}\text { Floor } \\
\text { tile }\end{array}$ & $\begin{array}{l}\text { Bathroom } \\
\text { \& WC }\end{array}$ & $\rightarrow \begin{array}{c}\text { Doors and } \\
\text { windows }\end{array}$ & $\rightarrow$ Painting \\
\hline
\end{tabular}

Figure 1 Single story house construction sequence.

The single-story house construction sequence in Figure 1 is then simulated in SIMUL8 utilizing different inter-arrival times as depicted in Figure 2.

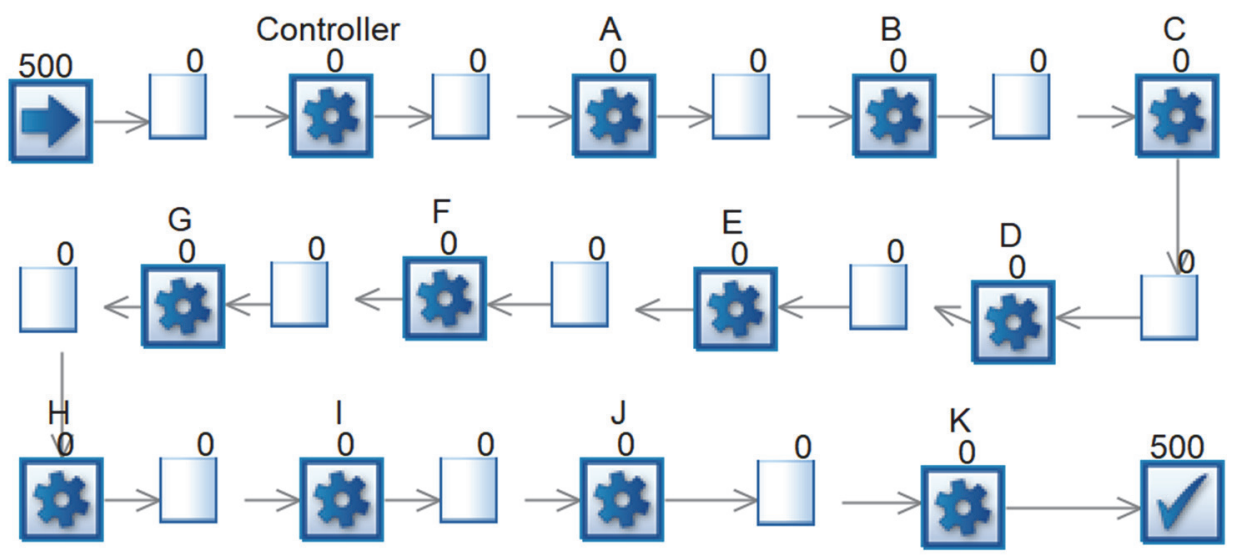

Figure 2 The simulation of single-story house construction in SIMUL8. 


\section{Results and discussion}

The simulation result with various inter-arrival times ranging from twenty to ten days is shown in Table 2.

Table 2 Simulation Result

\begin{tabular}{ccccc}
\hline $\begin{array}{c}\text { Inter- } \\
\text { arrival } \\
\text { time } \\
\text { (day) }\end{array}$ & $\begin{array}{c}\text { Cycle } \\
\text { time } \\
\text { (day) }\end{array}$ & $\begin{array}{c}\text { Standard } \\
\text { deviation } \\
\text { (day) }\end{array}$ & $\begin{array}{c}\text { Throughput } \\
\text { (house/day) }\end{array}$ & $\begin{array}{c}\text { Work in } \\
\text { process } \\
\text { (house) }\end{array}$ \\
\hline 20 & 68 & 0.00 & 0.050 & 3.38 \\
\hline 19 & 68 & 0.00 & 0.052 & 3.55 \\
\hline 18 & 68 & 0.00 & 0.055 & 3.75 \\
\hline 17 & 68 & 0.00 & 0.058 & 3.97 \\
\hline 16 & 68 & 0.00 & 0.062 & 4.21 \\
\hline 15 & 68 & 0.00 & 0.066 & 4.49 \\
\hline 14 & 68 & 0.00 & 0.071 & 4.81 \\
\hline 13 & 317.5 & 144 & 0.071 & 22.46 \\
\hline 12 & 567 & 289 & 0.071 & 40.11 \\
\hline 11 & 816.5 & 433 & 0.071 & 57.75 \\
\hline 10 & 1066 & 578 & 0.071 & 75.39 \\
\hline
\end{tabular}

The correlation between the work in process, the cycle time, and the throughput is shown in Figure 3.

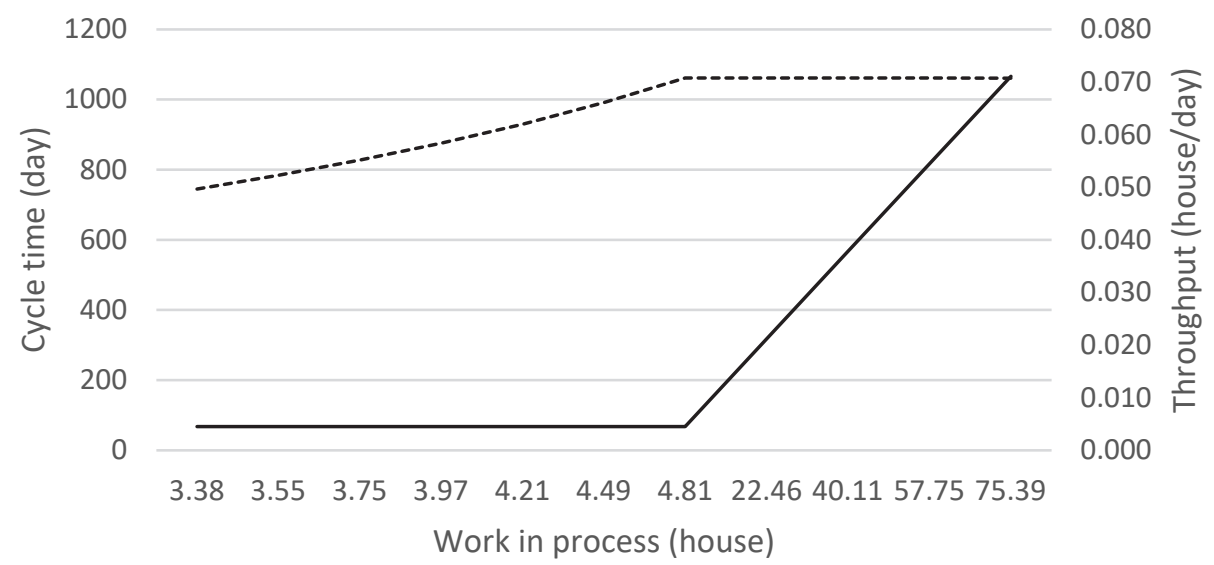

— Average CT (day) ------- Average TH (house/day)

Figure 3 The correlation between work in process, cycle time, and throughput.

The simulation result in Table 2 shows that there is a negative correlation between the inter-arrival time and the work in process, that is the decrease in the inter-arrival time will increase the work in process. 
The simulation results that are shown in Table 2 and Figure 3 can be construed as follows.

- The maximum production capacity of the project is equal to its maximum throughput that is 0.071 house per day on average.

- The cycle time stays constant at 68 days despite the increase in the work in process due to the decrease in the inter-arrival time. This condition stays the same until the maximum production capacity of the project or its maximum throughput is reached.

- The maximum throughput is reached when the work in process number is equal to 4.81 or when the inter-arrival time is equal to 14 . Less than 14 inter-arrival time will not increase the throughput but will increase the cycle time.

- The optimum production system is achieved when the throughput is maximum and the cycle time is minimum, which is achieved by keeping the work in process at 4.81 or setting the inter-arrival time to 14 days.

\section{Conclusions}

This study demonstrates that workflow-based planning and simulation methods can effectively explain the correlation between throughput, work in process, and cycle time in a large number of house construction projects which is often the case after an earthquake, which cannot be explained by the activity-based planning method. Therefore, the utilization of the workflow-based planning method in a construction project with repetitive activities can complement the activity-based planning method which is commonly used in a construction project.

\section{References}

1. Ballard, G. and G. Howell. What Kind of Production is Construction. in 6th International Conference on Lean Construction. 1998. Guarujá, Brazil.

2. Bashford, H., et al., Implications of Even Flow Production Methodology for U.S. Housing Industry. Journal of Construction Engineering and Management, 2003. 129(3): p. 330-337.

3. Gann, D.M., Construction as a manufacturing process? Similarities and differences between industrialized housing and car production in Japan. Construction Management and Economics, 1996. 14(5): p. 437 - 450.

4. Blismas, N. and R. Wakefield, Drivers, constraints and the future of offsite manufacture in Australia. Construction Innovation: Information, Process, Management, 2009. 9(1): p. 72-83.

5. Koskela, L. Management of production in construction: A theoretical approach. in 7th Annual Conf. of the Int. Group for Lean Construction. 1999. Univ. of California, Berkeley, California: International Group for lean Construction.

6. Winch, G.M., Towards a theory of construction as production by projects. Building Research \& Information, 2006. 34(2): p. 154 - 163.

7. Sawhney, A., et al., Impact of Inspected Buffers on Production Parameters of Construction Processes. Journal of Construction Engineering \& Management, 2009. 135(4): p. 319-329.

8. Gharaie, E., R. Wakefield, and N. Blismas, Explaining the Increase in the Australian Average House Completion Time: Activity-based versus Workflow-based 
Approach. Australasian Journal of Construction Economics and Building, 2010. 10(4): p. 34-49.

9. Bashford, H., K.D. Walsh, and A. Sawhney, Production System Loading-Cycle Time Relationship in Residential Construction. Journal of Construction Engineering and Management, 2005. 131(1): p. 15-22.

10. Mubarak, S.A., Construction Project Scheduling and Control. 2nd ed. 2010, Hoboken, N.J.: John Wiley \& Sons, Inc.

11. Walsh, K.D., A. Sawhney, and H.H. Bashford, Production Equations for UnsteadyState Construction Processes. Journal of Construction Engineering and Management, 2007. 133(3): p. 254-261.

12. Tommelein, I.D. and D.R. Riley, Parade game: Impact of work flow variability on trade performance. Journal of Construction Engineering \& Management, 1999. 125(5): p. 304.

13. Howell, G., A. Laufer, and G. Ballard, Interaction between Subcycles: One Key to Improved Methods. Journal of Construction Engineering and Management, 1993. 119(4): p. 714-728.

14. Hopp, W.J. and M.L. Spearman, Factory physics. 3rd ed. 2008, New York: McGraw-Hill/Irwin.

15. Sawhney, A., et al., Construction II: simulation of production homebuilding using simphony, in Proceedings of the 33nd conference on Winter simulation. 2001, IEEE Computer Society: Arlington, Virginia. p. 1521-1527.

16. Sawhney, A., et al. A Discrete Event Simulation Model to Analyze the Residential Construction Inspection Process. 2005. Cancun, Mexico: ASCE.

17. Fadjar, A., et al., The effect of resource availability on completion time in volume home building, in The 19th International CIB World Building Congress, S. Kajewski, K. Manley, and K. Hampson, Editors. 2013, Queensland University of Technology: Brisbane. 